\title{
Digitalization in Business: Examining the Antecedents of Repurchase Intention Using Traveloka Application
}

\author{
Rosdiana Sijabat \\ Department of Business Administration, Atma Jaya Catholic University of Indonesia, Jakarta, Indonesia.
}

\begin{abstract}
In the current technological development, internet and smartphone users in conducting transactions online continue to experience growth. This development is mainly in the entertainment and leisure industry to provide opportunities for businesses to create an application in the field of online travel, one of which is Traveloka. This study aims to analyze the impact of information quality, application design, and satisfaction on repurchase intention with social media engagement as a mediating variable. Data were collected deploying the nonprobability sampling method through online questionnaires, 400 responses were received and 392 included for data analysis. Research participants were the general public who had used the Traveloka application previously. Structural equation modelling (SEM) has been used to examine the association of the constructs, including information quality, application design, satisfaction, social media engagement and repurchase intention. The results indicate that the quality of information, application design, payment methods, and security and privacy had a positive and significant effect on customer satisfaction. Social media engagement does not statistically significant mediates the impact of information quality and application design on repurchase intention in the Traveloka application.
\end{abstract}

Keywords - Information quality; mobile application; intention to repurchase; application design; social media engagement.

\begin{abstract}
Abstrak
Dalam perkembangan teknologi saat ini, pengguna internet dan smartphone dalam melakukan transaksi secara online terus mengalami perkembangan. Perkembangan ini terutama dalam industri entertainment dan leisure sehingga memberikan peluang bagi para pelaku usaha untuk menciptakan sebuah aplikasi di bidang travel online, salah satunya adalah Traveloka. Penelitian ini bertujuan untuk menganalisis pengaruh kualitas informasi pada aplikasi Traveloka, desain aplikasi, dan kepuasan terhadap niat pembelian ulang dengan variabel social media engament sebagai variabel mediasi. Jumlah responden yang dianalisis adalah 392 responden yang berdomisili di Provinsi DKI Jakarta dan pernah menggunakan aplikasi Traveloka. Pengambilan sampel dilakukan dengan metode non-probability sampling melalui penyebaran kuesioner online dengan pertanyaan menggunakan skala Likert yang kemudian diolah menggunakan structural equation model (SEM) dengan PLS. Hasil penelitian menunjukkan kualitas informasi, desain aplikasi, serta kepuasan berpengaruh positif dan signifikan terhadap kepuasan pelanggan. Kepuasan pelanggan secara statistik berpengaruh terhadap niat pembelian ulang pada aplikasi Traveloka sedangkan social media engagement tidak memiliki peran mediasi.
\end{abstract}

Kata kunci- Kualitas informasi; aplikasi seluler; intensi pembelian ulang; disain aplikasi; social media engagement.

\section{INTRODUCTION}

Increasing acceptance, adoption, and use of mobile applications opens the market for new consumers and enhances service delivery by using cellular technology features properly (Middleton, Scheepers, \& Tuunainen, 2014). Improved technology that fits quickly is marked by changes in the types of internet-based applications and using smartphones. This rapid development makes consumers depend on technology using unique 
application systems, particular kinds of cellular applications (Kim, Kim, \& Wachter, 2013). Responding to the development of information technology, manufacturers and companies in the industry also quickly use mobile applications to reach consumers to buy products and services using smartphones (Mo Kwon, Bae, \& Blum, 2013).

Shopping uses online shopping applications, often with many online shopping sites, as well as online shopping applications. The development of online shopping is wrong to increase spending utilizing the internet in Indonesia. The internet penetration rate is only 53.7 percent, lower than many countries in the Asia Pacific, but Indonesia is one of the countries with the highest number of internet users in the world (Statista, 2019). Indonesians frequently access the internet through cellphones. In 2018, around 30 percent of Indonesians accessed the internet from their cells. This number is estimated expected to surge to almost 36 percent by 2023 . Indonesians spend an average of 66 minutes on the internet via their smartphones every day, and smartphone users in Indonesia spend an average of 69 minutes every day for cellular applications (Statista, 2019).

Regarding digital purchases, the Indonesian market is showing an optimistic transition. Indonesia's ecommerce business reached around \$ 13.6 billion in 2017. Although it is still approximately 0.6 percent of its entire retail market, e-commerce has grown at an extraordinary rate, raising more than a third in 2016 and 2017 , and is estimated will grow further (JP Morgan, 2019). This e-commerce rise is due in part to the increasing number of internet users. According to Statista (2020a), as of June 2019, online reductions in Indonesia had been more than 50 percent, with internet users of around 143.26 million people. While mobile internet usage is a double-digit growth rate and currently stands above 30 percent of Indonesia's total population. As in Figure 1, in 2017, internet users rose by around 87 million people, up to 95.2 million in the following year, and reached a total of 119.4 million in 2019 , then predicted to reach 149.9 million in the year 2023 .

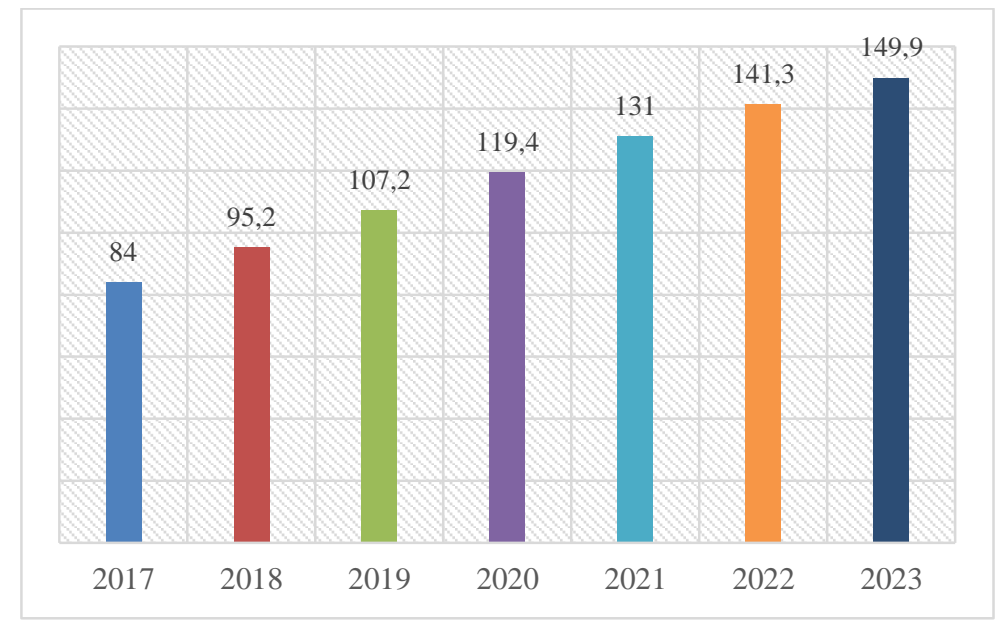

Note: $2020-2023$ are projected figure.

Figure 1. Number of internet users in Indonesia from 2017 to 2023 (in millions) (Source: Statista, 2020a).

The increasing online spending in Indonesia follows the rising number of internet users. According to GlobalWebIndex, Indonesia has the highest level of e-commerce usage among any country in the world, with 90 percent of the country's internet users aged between 16 and 64 who report that they have purchased products and services online (www.globalwebindex.com, 12 / 02/2020). Like data from Statista (2020b), mentioning that more than 100 million Indonesians buy consumer goods online in 2018, with spending on food products soaring 30 percent year-on-year, this figure shows the critical role of online spending in Indonesia in the future. It places Indonesia in the position of the five fastest-growing online wholesale markets in the world.

The number of online shoppers in Indonesia was only around 24.9 million in 2016, then slightly increased to 28.1 million in 2017, 31.6 million, and 35.5 million in 2018 and 2019 with an average growth of 12.5 percent from 2016 to 2019. The number of online shoppers grew by about 10.4 percent in 2020, with the number of online shoppers of 39.2 million. Figure 2 below show the number of online shoppers in Indonesia. 


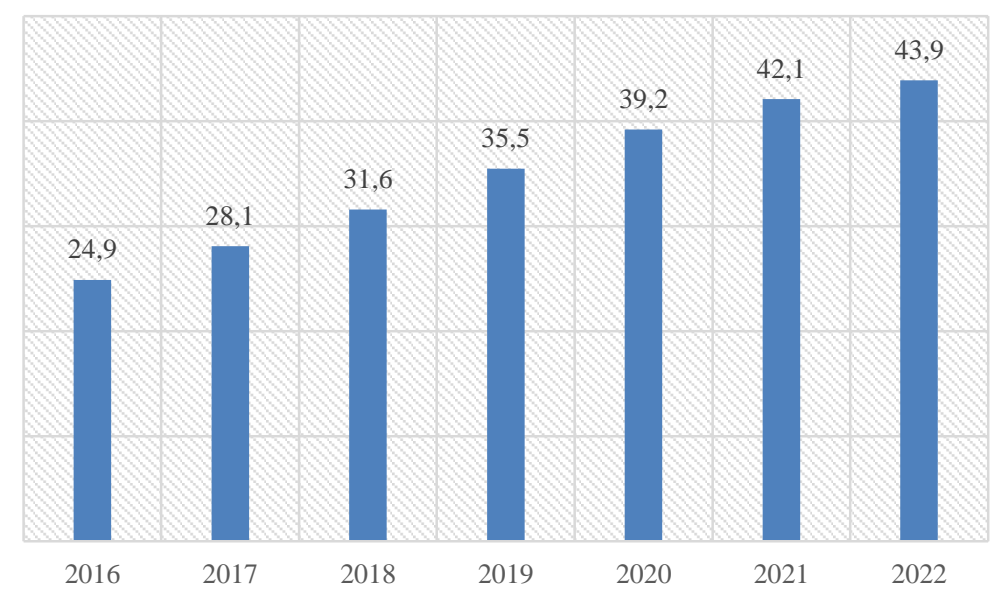

Figure 2. Number of Online Shoppers in Indonesia from 2017 to 2023 (in millions) (Source: Kamath, 2019).

Increasing e-commerce transactions and online shopping mobile applications make online payment applications also higher in Indonesia. Residents no longer only use traditional payment methods or cash, but payments using a digital wallet are increasingly attractive. The number of transactions using digital payment and e-money also continues to rise. According to the Statista report (2020b), the number of e-money transactions in Indonesia from 2011 to 2018. In 2018, the volume of e-money transactions amounted to around 5.2 billion, while only 41 million online transactions were recorded in 2011. According to JP Morgan (2019), a popular ecommerce payment method used by Indonesian residents is a digital wallet. Digital wallet in Indonesia is the fastest rising payment method, growing at a rate of 29 percent in 2019 and predicted to develop to 47 percent by 2021 (JP Morgan, 2019). The increasing use of digital wallets is driven by increased smartphone penetration. One in five of all online shopping in Indonesia with well-known brands uses digital wallets, including PayPal ${ }^{\circledR}$ and Go-Pay or OVO (JP Morgan, 2019). Figure 3 below show the number of e-money transaction in the period 2011-2019.

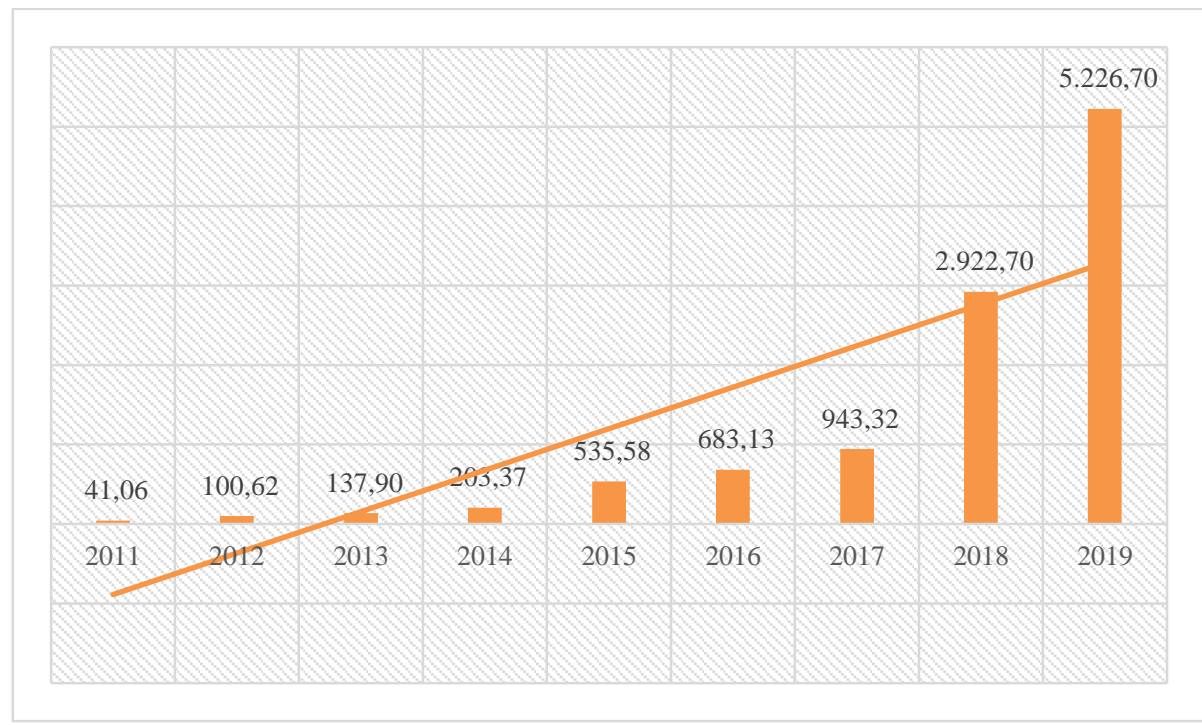

Figure 3. Number of e-money transactions in Indonesia from 2011 to 2019 (in millions) (Source: Statista, 2020b). 
Indonesia has good potential in the tourism sector and also travel. Indonesia is a country with more than 17,000 islands in 34 provinces. Each of these provisions offers many choices for travel experiences and can be an attraction for tourist trips by both domestic and foreign tourists. For economic potential, with more than 261.12 million population and GDP per capita estimated to reach 5,790 USD in 2022, Indonesia's middle-class population is growing, and more than 31.65 million users shop online (Kamath, 2019).

The existence of technology has directly changed the whole concept of travel and tourism both in terms of demand and offering, and the use of technology has increased the ease of accessibility in the tourism sector (Januszewska, Jaremen, \& Nawrocka, 2015). The existence of technology shortens business processes in the travel sector, for example, by offering travel products carried out by travel agents online (OECD, 2018). Research results show an increase of about 51.8 percent of tourists who book trips through digital channels using mobile devices and 0.75 billion boarding passes sent via cellphones, is predicted to reach 1.5 billion by the end of 2019 (eMarketer's, 2015). According to Global Travel Intention Study (GITS) released data that in 2015, there was an increase in interest in traveling by Indonesians and domestic and ASEAN regions who did not need to use a visa but had planned to become one of the countries that experienced an increase in spending on vacation in 2013-2015 by 30\%. The development of information communication technology has also changed the way companies in the field of travel, such as travel agents and hospitality companies, do business and interact and communicate with consumers (Wang \& Wang, 2010). New communication technologies have led to increased productivity and efficiency in service delivery by enabling companies to provide services to consumers through more convenient channels, including in the tourism sector (Meuter, Ostrom, Bitner, \& Roundtree, 2003). Report from J.P. Morgan (2019) points out that in shopping online, Indonesians tend to spend time traveling, this transaction for traveling is the most popular e-commerce market segment in Indonesia, with a 58.9 percent share of all online sales, local sites, and Traveloka as the leading travel platform.

According to JP. Morgan (2019), for the category of local companies, Traveloka travel company is one of the most popular travel platforms in Indonesia. Traveloka is an online travel agent from Indonesia, established in February 2012. The company was originally a startup that functions as a ticket price comparison site, and a flight aggregator turned into a ticket sales service and expanded the business into offering hotel bookings. Traveloka developed into one of Southeast Asia's online travel companies, in addition to Indonesia, Traveloka also operates in Malaysia, Thailand, the Philippines, Vietnam, Singapore, and Australia. Traveloka provides various travel needs in one platform. Traveloka offers the purchase of airline tickets, hotels, trains, attractions \& activities, connectivity products, and airport transportation. Until early 2020, the Traveloka mobile app was downloaded more than 30 million times and made it the most popular travel booking application in Indonesia (www.traveloka.com). Figure 4 below show the top e-commerce merchant segments in Indonesia.

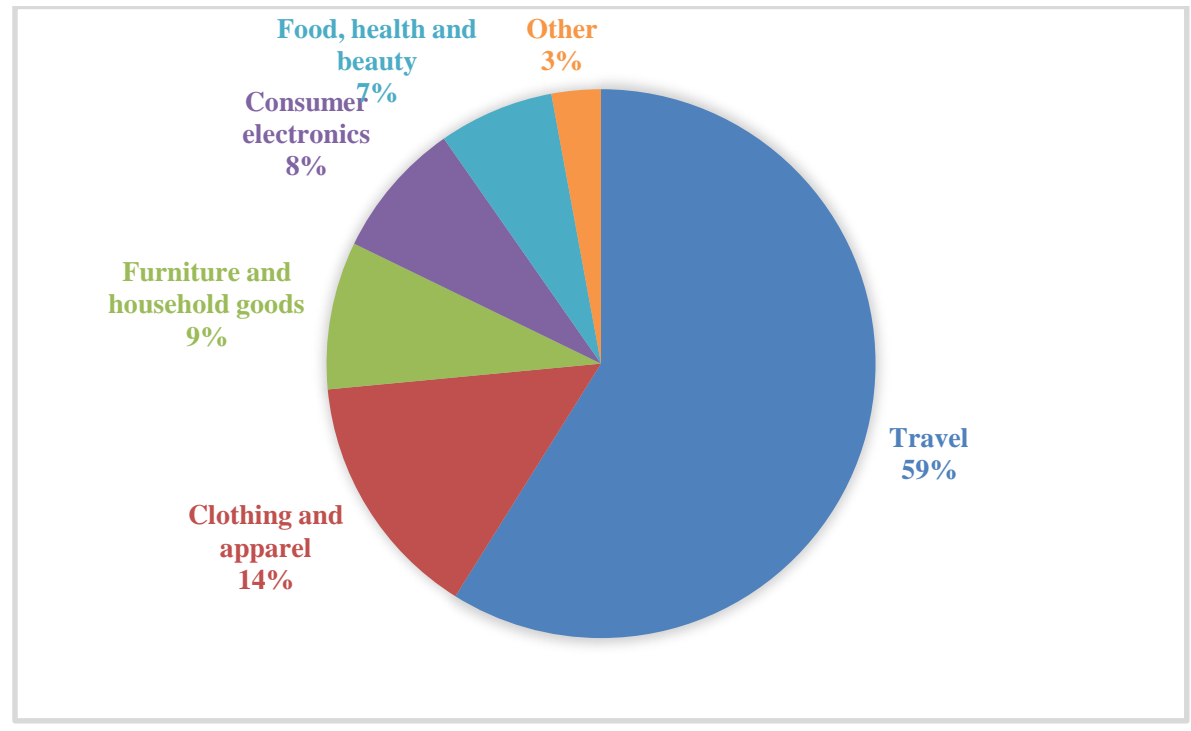

Fig. 4. Top e-Commerce Merhant Segments in Indonesia in to 2019 (Source: JP. Morgan, 2019). 
The discussion above indicates that the tourism industry and business traveling are the most dominant sectors in e-commerce transactions. Mobile applications and business websites will be increasingly important in the tourism and tourism business in the future. This study aims to analyze the factors that influence repurchase intention in the Traveloka application.

\section{LITERATURE REVIEW}

\section{A. Repurchase Intention}

Repurchase intention refers to the actions taken by someone in buying or using the product again (Ibzan, Balarabe \& Jakada, 2016). The repurchase is an action that shows a person's decision to reconnect with a retailer or supplier (Nguyen \& Tran, 2018). According to Ashfaq et al. (2019), repurchase intention occurs through an individual's assessment of purchasing a product or service again from the same company taking into account the current situation. Nguyen and Tran (2018) argue that repurchase refers to an intention to repurchase a product or service and a plan that is followed by positive word of mouth or recommendations to others. In online shopping using the application, to increase customer repurchase intentions, sellers often provide additional services as promotions, offer payment options that make it easier for consumers or provide other values that can attract consumers' purchase expectations hoping to increase repurchase intentions (Ibzan, Balarabe \& Jakada, 2016).

In online shopping, e-commerce will succeed if it can create buyer interest to do become a customer to repurchase. Repurchase intention occurs if the customer is satisfied with the service provided by the online service provider (Zhan et al., 2011). Consumers who are happy with a brand of product or service consumed or used will make a repeat purchase. The results of a study from Bulut (2015) revealed that electronic satisfaction and electronic trust have a higher level of influence on repurchase intentions in the online market. Therefore, customers are more likely to intend to buy back from a website when an online store can make customers more trusted and satisfied.

Referring to Nguyen and Tran's study (2018), the quality of information and design in online purchasing applications will create customer loyalty or repurchase intention. Study findings from Nguyen and Tran (2018) which measure the effect of service quality, system quality, information quality on the plan to repurchase smartphone-based hailing ride services in Vietnam shows that the quality of electronic services from information systems is a significant predictor of service quality and repurchase intention use the application. Specifically researching repurchases in the online travel sector, Razak, Ahmad, and Marimuthu (2016) also found that the quality of the travel agency's website had an impact on repurchase intentions. Website quality is a representation of quality information and also an attractive design and easy to learn. So based on the above discussion, it can be concluded that repurchase intention through an application to purchase using the internet is determined by the quality of information, the design of the application, and customer satisfaction when using the app in making a purchase.

\section{B. Information Quality}

Information is an essential part of both the website and the mobile application and influences consumers' decisions to make transactions in shopping (Guo, Lin \& Liu, 2012). Useful quality information is the key to success in e-commerce and online shopping (Sharma \& Lijuan, 2015). Bult (2016) suggests that quality information is accurate, reliable, formal, current, easy to understand. Information quality is the customer's perception of the quality of the information displayed on applications on mobile (Blut, 2016; Holloway \& Beatty, 2008). Information quality refers to the accuracy, completeness, presentation, and format of information provided by service providers (Elliot et al., 2013). Operationally, the right quality information is useful information that is current and accurate (Rieh, 2002). According to Azemi, Zaidi, and Hussin (2017), information quality is the perception of users who get information and provide benefits for those who get information.

A mobile application is said to have quality information if the mobile app contains sufficient content that is reliable, sufficient, and has useful content (Guo, Lin \& Liu, 2012). The success of an information and technology application is determined by the quality of the information (DeLone \& McLean, 2004). DeLone and McLean suggest that the quality of data is influenced or determined by relevance, accuracy, timely, and trustworthy. Relevance (relevance) which means that information must provide benefits to the wearer, the 
suitability of the data for each person is different from one another. Accuracy (accuracy) which means that information must be free from mistakes and not biased or misleading and must reflect the intent. Inaccuracies can occur because the source of information has been interrupted, or there is an intention to damage or change the original data. Timely (timeliness), which means that information generated or needed must not be late (obsolete). Outdated information does not have good value, so if it is used as a basis for decision making, it will have fatal consequences or errors in decisions and actions. Such conditions cause the high value of information, so the speed to get, process, and send it requires the latest technologies. Trusted information means the data presented in an information system must be trusted so that users can use it.

Previous research shows that the quality of information has a positive effect on customer satisfaction. If the information in the mobile application is accurate, then consumers tend to be satisfied and plan to repurchase. Hence, in this study, the relationship between information quality and repurchase intention is predicted as follow:

\section{H1: Information quality of mobile websites will have a positive impact on consumer satisfaction}

\section{Application Design}

Application design is one of the substantial factors that attract individuals to make purchases using a mobile purchasing application (Phattharakittisakul \& Juntongjin, 2016). As on a website, the design of a cell phone application will influence the choice of applications for consumers and also change them in making purchasing decisions. According to Hoehle and Venkatesh (2015), application design is the extent to which users perceive that mobile applications are generally well-designed and determined empirically by four dimensions; measure branding, data preservation, instant start, and orientation. An online or mobile purchase application offers new opportunities for companies to communicate with and satisfy their target audience (Wen et al., 2014). Online purchasing applications or mobile cellular and then developed into a phenomenon and trend that emerged quickly. Various companies then use mobile apps as a means of interactive communication with consumers (Yang, 2013). Therefore, a mobile application that provides an enjoyable shopping experience is vital to attract consumers and maintain customer loyalty (Blut, 2016).

According to Kim et al., (2013), mobile application design impacts consumers because it shapes experiences and involvement (Kim, Lin \& Sung 2013). Therefore, a mobile application provider needs to build the best design application, simple, useful and looks good, because of application users like a simple, comfortable and easy to use experience with vibrant visual images (Ryan \& Jones, 2012). In the study of mobile shopping applications, Phattharakittisakul and Juntongjin (2016) found that the design of a well-designed mobile shopping application will create consistency following user expectations. They also found that good mobile app design builds and influences user satisfaction, which in turn will generate loyalty and use mobile app shopping. Their research is similar to findings from Hoehle and Venkatesh (2015), who examined the experience of Apple mobile application users using four dimensions of cellular application design: branding, data preservation, instant start, and orientation. If the mobile application provides these four dimensions well, then the user views the design of the mobile app as well. When users consider a mobile application providing a good plan, user loyalty to the mobile application is formed.

Therefore, it is very appropriate to apply application design factors to explain commitment in mobile shopping applications. Thus, in this study, the relationship between Application design and repurchase intention is posited as follows:

\section{H2: Application design has a positive impact on repurchase intention.}

\section{Satisfaction}

Satisfaction is both a cognitive and emotional response related to a particular focus (expectations, consumption experiences, products), and the reaction occurs for a specific time (after consumption, based on accumulated knowledge, after choice) (Giese \& Cote, 2000). In the research of Giese and Cote, they argue that customer satisfaction can be identified by the cognitive response given by someone when there is an experience when buying a selected product at a specific time (for example, post-purchase or post-consumption). The cognitive response itself can be interpreted as a response that is closely related to the knowledge of one's skills and information about something. This response arises when there is a change in what is understood by the public. Giese and Cote also added that the intention for follow-up action, including repurchase intention, is a 
direct response to satisfaction with the previous usage felt by consumers. A similar definition is also mentioned by Chu (2002), which defines customer satisfaction as an emotional response to the use of a product or service and is also a complex human process, which involves cognitive and affective processes, as well as other psychological and physiological influences.

Dilpazir and Amin (2015) define customer satisfaction as the company's ability to meet the needs and desires of customers in connection with their expectations before receiving a product or service. According to Dharmavaran and Nitalla (2018), satisfied customers will continue to be customers for a more extended period, i.e., buy more products and will not be influenced by prices or competitors. The concept of customer satisfaction is an essential issue in marketing thinking and practice because it is one of the most significant determinants of repeat purchases, repeat sales, the emergence of positive word of mouth, and the creation of customer loyalty (Dharmavaran \& Nitalla, 2018). The ability to understand behavior and produce values under customer expectations it will create satisfaction for these customers and ultimately will have an impact on customer loyalty (Dilpazir \& Amin, 2015). Wang and Liao (2007) define consumer satisfaction of online purchases as cognitive responses after using cellular trading activities stimulates by several aspects, such as service quality, information quality, and system quality. Molla and Licker (2001) found that satisfaction in shopping online is a reaction or feeling of consumers in connection with their experience with an e-commerce system. The satisfaction illustrates the fulfillment of customer expectations. Tandon et al. (2017) add that in an e-commerce environment, customer satisfaction impacts retaining old customers and introducing new customers. Razak, Ahmad, and Marimuthu (2016) emphasize that different research results showing the main factor for repurchase intention are satisfaction. Previous research shows shopping satisfaction using a mobile application will lead to future purchase intentions (Razak, Ahmad, and Marimuthu, 2012). Thus, the following hypothesis is proposed:

H3: Consumer satisfaction will have a positive influence on repurchase intention.

\section{E. Social Media Engagment}

Social media is increasingly popular as an essential platform for obtaining various information. Social media platforms such as Facebook, LinkedIn), microblogs, Twitter, or diverse content sharing communities such as YouTube and Instagram are often used to share experiences, such as travel and vacation experiences (Yoong \& Lian, 2019). According to Chen (2017), customer involvement in social media serves as an essential factor in arousing buying intentions among consumers. Individuals often use social media platforms to interact with other consumers and also to find information (Bernoff \& $\mathrm{Li}, 2011$ ). The development of this social media plate causes individuals to no longer to depend on traditional media but has relied on the search and dissemination of information through social media (Keller, 2009).

This social media platform has evolved rapidly since the advent of information technology and the Internet and has quickly replaced the traditional word of mouth into electronic word-of-mouth (Chen (2017; Keller, 2009). E-WOM is developed into an informal means of communication. Further, e-WOM information was also used as a reference in purchase and repurchase intention (Eisingerich et al., 2015; Bernoff \& Li, 2011 ). If consumers get a review of a product or service on social media is positive, it will encourage consumers to make purchases or repurchases. Conversely, if the reviews obtained are negative, then the consumer does not decide to buy or not make a repeat purchase (Yoong \& Lian, 2019; Vij \& Sharma, 2013). Thus, to explore the mediating role of social media engagement on the impact of quality information, application design, and satisfaction on repurchase inference, the following hypothesis will be examined:

H4: Social media engagement mediates the impact of information quality on repurchase intention.

H5: Social media engagement mediates the impact of application design on repurchase intention.

H6: Social media engagement mediates the impact of satisfaction on repurchase intention.

\section{RESEARCH METHODOLOGY}

\section{A. Data Collection and Instruments}

A survey using Google Forms was conducted to collect data from targeted respondents. The constructs studied were information quality, application design, social media engagement, and repurchase intention. All items in the form of Likert Scale 1 to 5, ranging from (1) "strongly disagree" to (5) "strongly agree." The scale gives a number or value to the object to be studied so that its characteristics can be measured (Sekaran \& 
Bougie, 2016). All construction and reflective items are measured using items that have been used and validated in various previous studies (Table 1).

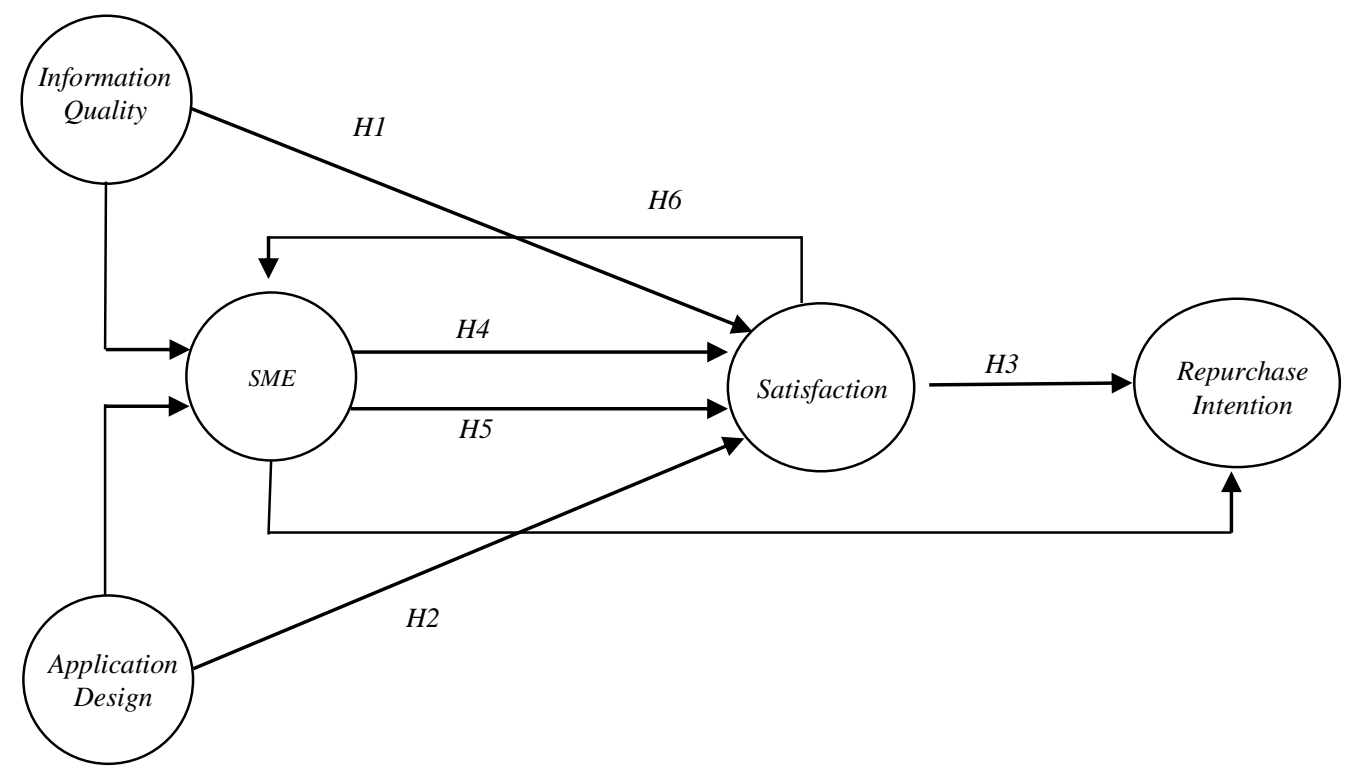

Figure. 5. Research Model

Table 1. Constructs and items used.

\begin{tabular}{|c|c|c|}
\hline Latent Variables & Items/Questions & Reference \\
\hline Information Quality & $\begin{array}{l}\text { - Information on the application provides information about what I need to make } \\
\text { a purchase (IQ1) } \\
\text { - The application meets my information needs (IQ2) } \\
\text { - Information on this application is effective (IQ3) }\end{array}$ & $\begin{array}{l}\text { Barnes \& Vidgen } \\
(2002) \text {; Holloway } \\
\text { and Beatty (2008) }\end{array}$ \\
\hline Application Design & $\begin{array}{l}\text { - This mobile application allows me to get information needs that have been } \\
\text { tailored to the needs of customers (AP1) } \\
\text { - This mobile application has an interactive feature that helps me make } \\
\text { purchases quickly and effectively (AP2) } \\
\text { - I can interact with the mobile app to get information tailored to my specific } \\
\text { needs (AP3) }\end{array}$ & $\begin{array}{l}\text { Blut (2016) Wen et } \\
\text { al., (2014); } \\
\text { Hoehle \& Venkatesh } \\
(2015) \text {., }\end{array}$ \\
\hline Satisfaction & $\begin{array}{l}\text { - I am satisfied with this mobile application (S1) } \\
\text { - This mobile application is the preferred application (S2) } \\
\text { - This mobile application always meets my needs (S3) }\end{array}$ & $\begin{array}{l}\text { Holloway and } \\
\text { Beatty (2008) }\end{array}$ \\
\hline $\begin{array}{l}\text { Social Media } \\
\text { Engagement }\end{array}$ & $\begin{array}{l}\text { - I want the Traveloka application to do interactive activities with customers } \\
\text { through social media sites (SME1) } \\
\text { - I want the Traveloka application to keep me updated on the latest products on } \\
\text { social media sites (SME2) } \\
\text { - I followed information about Traveloka through various social media sites } \\
\text { (SME3) }\end{array}$ & $\begin{array}{l}\text { Yoong \& Lian, } \\
\text { (2019); Chen } \\
\text { (2017); Vij \& } \\
\text { Sharma (2013). }\end{array}$ \\
\hline $\begin{array}{l}\text { Repurchase } \\
\text { Intention }\end{array}$ & $\begin{array}{l}\text { - I will make more purchases through this mobile application in the future (RI1) } \\
\text { - I will increase purchases through this mobile application (RI2) } \\
\text { - I will intensify purchases through this mobile application (RI3) }\end{array}$ & $\begin{array}{l}\text { Zeithaml et al. } \\
\text { (1996); Chen \& } \\
\text { Bibb (2010). }\end{array}$ \\
\hline
\end{tabular}

The sample size for the indefinite population is calculated using formula of Lwanga; Lemeshow and WHO (1990):

Where:

$$
n=z^{2} p(1-p) / d^{2}
$$

$\mathrm{n}=$ number of samples

$\mathrm{z}=$ standard error

$\mathrm{p}=$ population proportion 


$$
\begin{aligned}
& \mathrm{n}=\left(1.96^{2)} \times(0.5)(1-0.5) / 0.1^{2}\right. \\
& \mathrm{n}=96.04
\end{aligned}
$$

The minimum number of respondents or samples was 96, but according to Sekaran and Bougie (2016), the right sample size for a study ranged from 30 to 500 respondents. With this in mind, around 500 targeted samples were asked to fill out a questionnaire. After filtering data for missing values and other problems such as the same value for all questions, the number of valid responses to be analyzed was 392 respondents.

\section{B. Data Analysis}

This study employs modeling of the least-squares structural equation (PLS-SEM) to test the research hypotheses by following the methodology of Wong (2016), Lowry and Gaskin (2014), and Hair et al., (2019). PLS-SEM enables one to estimate complex models with many constructs, indicator variables, and structural paths without imposing data distribution assumptions (Hair et al., 2019). PLS-SEM is also a causal-predictive approach that emphasizes predictions in estimating statistical models that contain causal explanations (Hair et al., 2019). But the main reason for using PLS-SEM is to evaluate complex models with many constructs, indicator variables, and structural paths using data that do not have to meet distribution assumptions (MorenoGarcia (2017).

Data analysis uses the SmartPLS 3.0 software Ringle, Wende, \& Becker, 2015). The measurement model examines the reliability and validity of the constructs. The validity of the construct is evaluated through convergent validity and discriminant validity values, namely by looking at the value of outer loadings, average variance extracted (AVE). Construct is valid if the outer loading is higher than 0.708 . The average variance extract (AVE) value has to be higher than 0.50 (Wong, 2016). Also, it checks discriminant validity, which is to see the square root value of the average variance extract (AVE) Fornell-Larcker, the value of AVE between constructs one against the construct itself is higher when compared with AVE values between the same variables and other constructs (Fornell \& Larcker, 1981). The construct reliability on the outer model is examined by looking at the composite reliability (CR) and Cronbach's alpha values, the CR and Cronbach's alpha values greater than 0.70 indicate that the construct analyzed has high reliability (Wong, 2016).

Structural models were analyzed by looking at the Variance Inflation Factor (VIF), the coefficient of determination $\left(\mathrm{R}^{2}\right)$, and $\mathrm{Q}^{2}$-Value (Hussaini et al., 2018; Wong, 2016). VIF is used to evaluate the collinearity of formative indicators. The coefficient of the structural model for the relationship between constructs comes from estimating a series of regression equations. Before assessing structural relationships, collinearity must be examined to ensure the regression results are not biased-multicollinearity test, which aims to provide that the independent variables do not correlate with each other. VIF values above 5 are indicative of possible colinearity problems among the predictor constructors, but colinearity problems can also occur at VIF values lower than 35. Ideally, VIF values should be close to 3 and lower (Hair et al., 2019). Next is the value of $\mathrm{R}^{2}$, which is the measurement of the variance described in each endogenous construct, which is a measure of the explanatory power of the model (Shmueli \& Koppius, 2011). $\mathrm{R}^{2}$ values range from 0 to 1 , with higher values indicating greater explanatory power. As a guideline, $\mathrm{R}^{2}$ values of $0.75,0.50$, and 0.25 can be considered substantial, moderate and weak (Henseler et al., 2009; Hair et al., 2019). The accuracy of the prediction of the PLS pathway model is also seen from the cross validated redundancy value for the endogenous factor of the reflective model based on the Stone-Geisser $Q^{2}$ value (Stone, 1974; Geisser, 1974). The $\mathrm{Q}^{2}$ value must be greater than zero to show that the model is relevant for predicting endogenous factors given (Hair et al., 2019). As a rule of thumb, $\mathrm{Q}^{2}$ values higher than $0,0.25$, and 0.50 illustrate the small, medium, and substantial predictive relevance of the PLS pathway model (Hair et al., 2019).

\section{RESULT AND DISCUSSION}

\section{A. Demographic Findings}

Respondents were dominated by adolescents, aged 18-24 years with 179 people and adults aged 25-31 years, with 159 people with the majority of high school and S1 graduates: two hundred thirty female respondents and 162 male respondents. Furthermore, respondents with income $<5$ million rupiah dominated 176 people with a proportion of 44.9 percent of the total of 392 respondents. 


\section{B. Measurement Model}

Based on the test of convergent validity on the value of loadings, all indicators have a loading value>0.70. Furthermore, testing the average variance extracted value (AVE) shows that all latent variables measured (IQ, $\mathrm{AD}, \mathrm{S}, \mathrm{RPI}$ ) and SME mediating variables have a higher value than the value of 0.5. The loadings and AVE values also mean that the Information Quality, Application Design, Satisfaction, Repurchase Intention, and SME variables can explain an average of more than half the variants of each constituent indicator. So it can be concluded that all indicators and latent variables in the model are convergent valid and have the right level of construct validity.

Table 2. Profile of Respondents

\begin{tabular}{clcc}
\hline Variable & Group & Frequency & Percent \\
\hline Age & $18-24$ years of age & 179 & 45.7 \\
& $25-31$ years of age & 159 & 40.6 \\
& $32-38$ years of age & 37 & 9.4 \\
& $39-45$ years of age & 11 & 2.8 \\
& < 46 years of age & 6 & 1.5 \\
Gender & Male & 162 & 41.3 \\
& Female & 230 & 58.7 \\
Income & < Rp 5000000 & 176 & 44.9 \\
& > Rp 5000000 - 10000000 & 142 & 36.2 \\
& S Rp 10000000 & 74 & 18.9 \\
& SMA & 72 & 18.4 \\
& SMA & 141 & 35.9 \\
& S1 & 154 & 39.3 \\
& S2 \& S3 & 25 & 6.4 \\
\hline
\end{tabular}

Based on testing Internal consistency reliability on the value of Cronbach's alpha shows that each latent variable has a good value that is between 0.70 to 0.90 . Furthermore, the CR value for each latent variable is higher than 0.70, so it can be concluded that the latent variables Information Quality, Application Design, Satisfaction, Repurchase Intention, and SME mediating variables have excellent reliability.

Table 3. Construct Validity and Reliability Test

\begin{tabular}{|c|c|c|c|c|c|}
\hline \multirow{3}{*}{ Latent Variables } & \multirow{3}{*}{ Indicators } & \multicolumn{2}{|c|}{ Convergent Validity } & \multicolumn{2}{|c|}{ Internal consistency reliability } \\
\hline & & Loadings & AVE & Cronbach's Alpha & $\mathrm{CR}$ \\
\hline & & $>0.70$ & $>0.50$ & $0.70-0.90$ & $>0.70$ \\
\hline Information Quality & IQ1 & 0.851 & 0.739 & 0.824 & 0.895 \\
\hline \multirow{2}{*}{ (IQ) } & IQ2 & 0.869 & & & \\
\hline & IQ3 & 0.860 & & & \\
\hline \multirow{4}{*}{$\begin{array}{l}\text { Application Design } \\
\text { (AD) }\end{array}$} & $\mathrm{AD} 1$ & 0.851 & 0.738 & 0.882 & 0.919 \\
\hline & AD2 & 0.841 & & & \\
\hline & AD3 & 0.866 & & & \\
\hline & $\mathrm{AD} 4$ & 0.878 & & & \\
\hline \multirow[t]{3}{*}{ Satisfaction (SF) } & S1 & 0.920 & 0.848 & 0.910 & 0.943 \\
\hline & $\mathrm{S} 2$ & 0.928 & & & \\
\hline & S3 & 0.914 & & & \\
\hline \multirow{3}{*}{$\begin{array}{l}\text { Repurchase Intention } \\
\text { (RPI) }\end{array}$} & RPI1 & 0.931 & 0.828 & 0.896 & 0.935 \\
\hline & RPI2 & 0.922 & & & \\
\hline & RPI3 & 0.875 & & & \\
\hline \multirow[t]{3}{*}{ SME } & SME1 & 0.856 & 0.776 & 0.858 & 0.912 \\
\hline & SME2 & 0.920 & & & \\
\hline & SME3 & 0.865 & & & \\
\hline
\end{tabular}

Based on the results of the Heterotrait-Monotrait (HTMT) test results, it was explained that all exogenous latent variables, namely Information Quality, Application Design, and Satisfaction, had a value $<0.85$ against Repurchase Intention latent variables including Satisfaction mediation variables by 0.830 and SME mediation variables by 0.063 . So it can be concluded that all latent variables have an excellent validity level. 
Based on the Fornell and Larcker test results table shows that the AVE value of each latent variable to the indicator has a higher value than the AVE value of each latent variable, including the SME mediating variable to the construct of other latent variables as evidenced by an asterisk $(*)$. So it can be concluded that all latent variables and moderation variables have a sufficient level of discriminant validity.

Table 4. Heterotrait-Monotrait Ratio (HTMT) Test

\begin{tabular}{cccccc}
\hline & $\begin{array}{c}\text { Application } \\
\text { Design }\end{array}$ & $\begin{array}{c}\text { Information } \\
\text { Quality }\end{array}$ & $\begin{array}{c}\text { Repurchase } \\
\text { Intention }\end{array}$ & SME & Satisfaction \\
\hline Application Design & & & & & \\
Information Quality & 0.798 & & & \\
Repurchase Intention & 0.741 & 0.793 & & \\
SME & 0.060 & 0.032 & 0.063 & \\
Satisfaction & 0.780 & 0.863 & 0.830 & 0.068 \\
\hline
\end{tabular}

Note: HTMT $<0.85$ (Kline, 2011), HTMT $<0.90$

Table 5. Fornell and Larcker's criterion analysis for checking discriminant validity

\begin{tabular}{ccccc}
\hline & $\begin{array}{c}\text { Application } \\
\text { Design }\end{array}$ & $\begin{array}{c}\text { Information } \\
\text { Quality }\end{array}$ & $\begin{array}{c}\text { Repurchase } \\
\text { Intention }\end{array}$ & SME \\
\hline Application Design & $\mathbf{0 . 8 5 9 *}$ & & & \\
Information Quality & 0.682 & $\mathbf{0 . 8 6 0 *}$ & & \\
Repurchase Intention & 0.660 & 0.682 & $0.910^{*}$ & $\mathbf{0 . 8 8 1}^{*}$ \\
SME & 0.039 & 0.019 & 0.056 & 0.062 \\
\hline Satisfaction & 0.702 & 0.748 & 0.749 & $\mathbf{0 . 9 2 1 *}$ \\
\hline
\end{tabular}

Note: *Average Variance Extracted (AVE) square root in bold.

Collinearity is assessed by the variance inflation factor (VIF) if the VIF value is five or more, it indicates a collinearity problem (Hair et al., 2019). Based on the collinearity assessment, it was found that the VIF of all constructs of independent variables has a VIF value of less than five so that it can be concluded that the construct of all indicators for each latent variable is free from multicollinearity problems.

Table 6. Collinearity Test

\begin{tabular}{|c|c|c|c|c|c|}
\hline Constructs & $\begin{array}{l}\text { Tolerance } \\
\text { Value }\end{array}$ & $\begin{array}{c}\text { Variance Inflation } \\
\text { Factor (VIF) }\end{array}$ & Indicators & $\begin{array}{l}\text { Tolerance } \\
\text { Value }\end{array}$ & $\begin{array}{c}\text { Variance Inflation } \\
\text { Factor (VIF) }\end{array}$ \\
\hline \multirow[t]{3}{*}{ Information Quality (IQ) } & $<10$ & 1.869 & IQ1 & $<10$ & 1.763 \\
\hline & & & IQ2 & & 1.966 \\
\hline & & & IQ3 & & 1.874 \\
\hline \multirow[t]{4}{*}{ Application Design (AD) } & $<10$ & 1.871 & $\mathrm{AD} 1$ & $<10$ & 2.238 \\
\hline & & & AD2 & & 2.200 \\
\hline & & & AD3 & & 2.347 \\
\hline & & & AD4 & & 2.409 \\
\hline \multirow[t]{3}{*}{ Repurchase Intention (RPI) } & & & RPI1 & $<10$ & 3.570 \\
\hline & & & RPI2 & & 3.306 \\
\hline & & & RPI3 & & 2.178 \\
\hline \multirow{3}{*}{ Satisfaction (S) } & $<10$ & 1.004 & $\mathrm{~S} 1$ & $<10$ & 3.008 \\
\hline & & & $\mathrm{S} 2$ & & 3.328 \\
\hline & & & S3 & & 2.890 \\
\hline \multirow[t]{3}{*}{ SME } & $<10$ & 1.004 & SME1 & $<10$ & 2.472 \\
\hline & & & SME2 & & 2.780 \\
\hline & & & SME3 & & 1.805 \\
\hline
\end{tabular}

Note: Constructs VIF value indicates inner model and Indicators VIF value indicates outer model. if a VIF value > 10 then collinearity occurs between constructs and indicators.

\section{Structural Model}

The path coefficient in PLS-SEM is examined for the relationship between the construct and the level of significance. The path coefficient of Information Quality (IQ) to Satisfaction (S) is 0.503 positive value, which 
means that Information Quality has a positive effect on Satisfaction. The coefficient of the Application Design (AD) path coefficient on Satisfaction (S) is 0.358 with a positive value, which means that Application Design has a positive effect on Satisfaction. The path coefficient value of Satisfaction (S) to Repurchase Intention (RPI) is 0.749 positive value, which means Satisfaction has a positive effect on Repurchase Intention. The specific indirect effect value of Information Quality (IQ) on Satisfaction (S) mediated by SME is -0,001, which is negative, which means that Information Quality on Satisfaction mediated by SME has a negative effect. The specific indirect impact of the Application Design (AD) on the Satisfaction (S) mediated by the SME is 0.002 positive, which means that the Application Design of the Satisfaction mediated by the SME has a positive effect.

Table 7. Significance Analysis of Direct and Indirect Effects

\begin{tabular}{|c|c|c|c|c|c|c|c|c|c|}
\hline & \multicolumn{3}{|c|}{ Path Coefficients } & \multicolumn{3}{|c|}{ Total Effects } & \multicolumn{3}{|c|}{ Specific Indirect Effects } \\
\hline & $\begin{array}{c}\text { Original } \\
\text { sample }\end{array}$ & $2.5 \%$ & $97.5 \%$ & $\begin{array}{l}\text { Original } \\
\text { sample }\end{array}$ & $2.5 \%$ & $97.5 \%$ & $\begin{array}{c}\text { Original } \\
\text { sample }\end{array}$ & $2.5 \%$ & $97.5 \%$ \\
\hline IQ $->\mathrm{S}$ & 0.503 & 0.415 & 0.595 & 0.502 & 0.415 & 0.594 & - & - & - \\
\hline$A D->S$ & 0.358 & 0.250 & 0.430 & 0.360 & 0.252 & 0.431 & - & - & - \\
\hline S -> RPI & 0.749 & 0.684 & 0.801 & 0.749 & 0.684 & 0.801 & - & - & - \\
\hline IQ $->$ SME & -0.015 & -0.166 & 0.122 & -0.015 & -0.166 & 0.122 & - & - & - \\
\hline $\mathrm{AD}->\mathrm{SME}$ & 0.049 & -0.141 & 0.180 & 0.049 & -0.141 & 0.180 & - & - & - \\
\hline SME $->S$ & 0.038 & -0.032 & 0.096 & 0.038 & -0.032 & 0.096 & - & - & - \\
\hline SME -> RPI & 0.009 & -0.068 & 0.080 & 0.038 & -0.060 & 0.110 & - & - & - \\
\hline IQ - SME - S & - & - & - & - & - & - & -0.001 & -0.013 & 0.005 \\
\hline$A D-S M E-S$ & - & - & - & - & - & - & 0.002 & -0.004 & 0.013 \\
\hline S - SME - RPI & - & - & - & - & - & - & 0.000 & -0.010 & 0.013 \\
\hline IQ - S - RPI & - & - & - & - & - & - & 0.377 & 0.299 & 0.453 \\
\hline$A D-S-R P I$ & - & - & - & - & - & - & 0.268 & 0.186 & 0.332 \\
\hline SME - S - RPI & - & - & - & - & - & - & 0.028 & -0.024 & 0.073 \\
\hline
\end{tabular}

Note: Results from 95\% two-tail testing bias-corrected and accelerated confidence intervals derived from bootstrapping 500 samples,

using the no sign changes option.

The t-table value for the confidence level of 95 percent $(\alpha=5 \%)$ at 2 ends (two tails) and the degree of freedom (degree of freedom) $=392-3-1=388$ is 2,25014. The t-statistic value for the influence of the Information Quality variable on Satisfaction is 10,729> t-table 2,25014, which means that the influence is significant, and H1 is accepted/supported. That is, the Information Quality variable has a positive effect on the Satisfaction variable of 0.503 and is significant with the sig value. 0,000 . This result indicates that when there is an increase in Information Quality by 1 unit of assessment, then Satisfaction will increase significantly by 0.503 units of assessment.

The t-statistic value for the effect of the Application Design variable on Satisfaction was 7,823> t-table 2,25014, which means that the impact was significant, and H2 in this study was accepted/supported. That is, the Application Design variable has a positive effect on the Satisfaction variable of 0.358 and is significant with the sig value. 0,000. It means that when there is an increase in the Application Design by 1 unit of assessment, the Satisfaction will increase significantly by 0.358 units of assessment. The t-statistic value for the effect of the Satisfaction variable on Repurchase Intention is 25,431> t-table 2,25014, which means that the impact is significant and H3 in this study is accepted/supported. That is, the Satisfaction variable has a positive effect on the Repurchase Intention variable of 0.749 and is significant with the sig value. 0,000 . One can say that if there is an increase in Satisfaction by 1 unit of assessment, the Repurchase Intention will increase significantly by 0.749 units of assessment.

Table 8. Hypotheses Testing

\begin{tabular}{clllll}
\hline & Hypothesis & Coefficient & t-Value & Sig. & Supported \\
\hline H1 & IQ - S & 0.503 & 10.729 & 0.000 & Yes *** \\
H2 & AD - S & 0.358 & 7.823 & 0.000 & Yes *** \\
H3 & S - RPI & 0.749 & 25.431 & 0.000 & Yes *** \\
H4 & IQ - SME - S & -0.001 & 0.147 & 0.883 & No \\
H5 & AD - SME - S & 0.002 & 0.452 & 0.652 & No \\
H6 & S - SME - RPI & 0.000 & 0.212 & 0.832 & No \\
\hline Note $* p<0.10 * * p<0.05, * * p<0.001$. & & &
\end{tabular}

The t-statistic value for the influence of the Information Quality variable on Satisfaction mediated by the SME variable is $0.147<\mathrm{t}$-table 2.225014, which means that the effect is not significant, and H4 is rejected / not supported. That is, the Information Quality variable harms the Satisfaction variable mediated by the SME 
variable of $-0,001$ and is not significant with the sig value. .883. This explains that when the SME mediates an increase in Information Quality by one assessment unit, the Satisfaction will decrease insignificantly by $-0,001$ assessment units. The t-statistic value for the effect of the Application Design variable on the Satisfaction mediated by the SME variable is $0.452<\mathrm{t}$-table 2.225014, which means that the impact is not significant and H5 is rejected. That is, the Application Design variable has a positive effect on the Satisfaction variable mediated by the SME variable of 0.002 and is not significant with the sig value. .652. The result implies that when there is an increase in the Application Design mediated by the SME by one assessment unit, the Satisfaction will increase insignificantly by 0.002 assessment units. The t-statistic value for the effect of the Satisfaction variable on Repurchase Intention mediated by the SME variable is $0.212<\mathrm{t}$-table 2.225014 , which means that the impact is not significant and H6 is rejected. That is, the Satisfaction variable has a positive effect on the Repurchase Intention variable mediated by the SME variable of 0,000 and is not significant with the sig value. 0.832 . This explains that when the SME mediates an increase in Satisfaction by 1 unit of assessment, the Repurchase Intention will not increase or decrease because it is 0 .

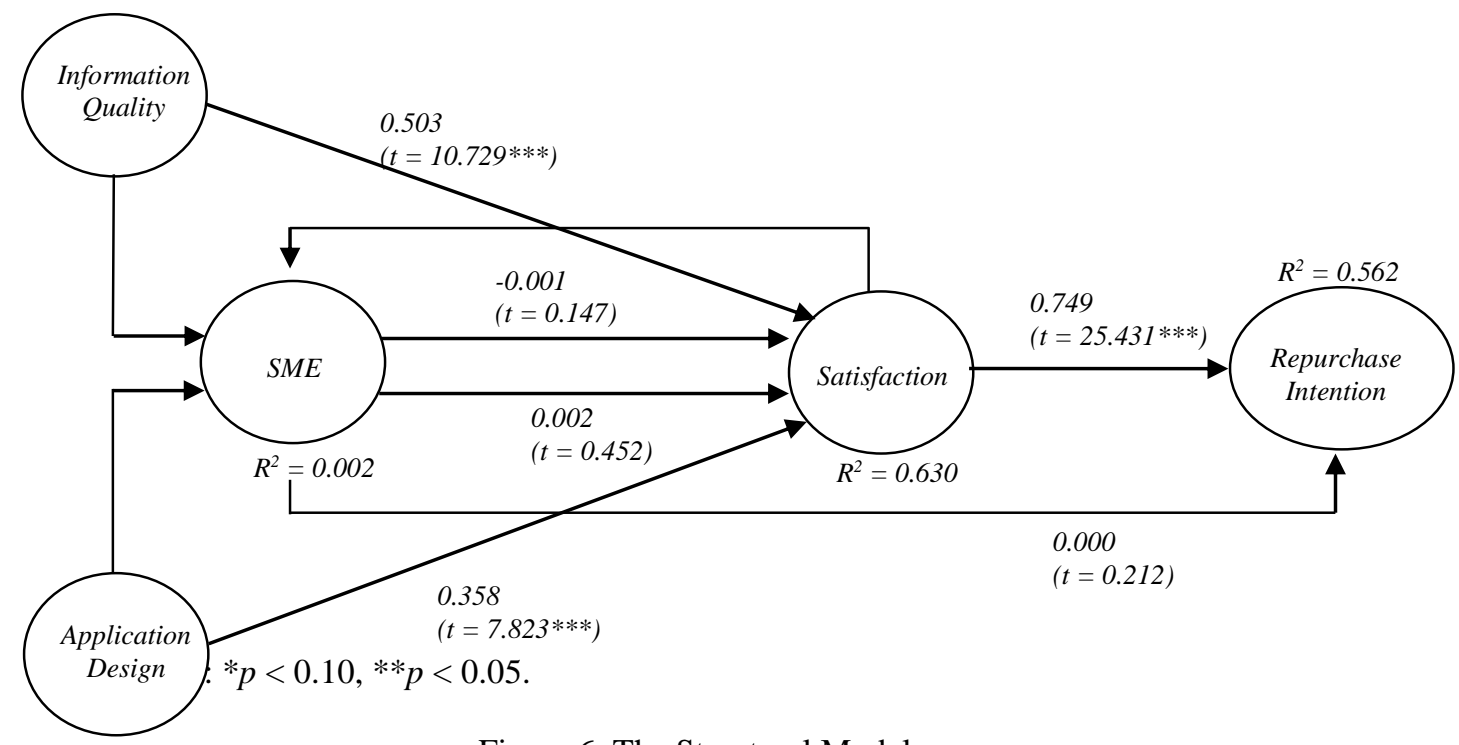

Figure 6. The Structural Model

The coefficient of determination or R2 is an essential measure in the evaluation of structural models. R2 values of $0.25,0.50$, and 0.70 are called the weak, moderate, and strong coefficient of determination, respectively (Hair et al., 2019). The R2 value of Repurchase Intention 0.562 can be interpreted that the Information Quality, Application Design, and Satisfaction variables can explain the variation of Repurchase Intention by $56.2 \%$ with a moderate (moderate) influence category while other variables outside the model explained $43.8 \%$. The value of R2 explains that the exogenous latent variable has an average predictive level in explaining the Repurchase Intention variable. The latent variable predictor (exogenous) Information Quality has a strong 0.366 effect (substance) on the criterion satisfaction variable at the structural model level. The f 2 effect size value of 0.185 can explain that the latent variable predictor of Application Design has a moderate (moderate) influence on the satisfaction criterion variable at the structural model level. The f2 effect size of 1.275 can explain that the latent variable predictor Satisfaction has a substantial impact on the Repurchase Intention criterion variable at the structural model level. Furthermore, the $\mathrm{Q}^{2}$ of 0.450 and 0.517 , which are larger than 0 , indicating that the values of the observed variables are well reconstructed and have functional predictive relevance.

Table 9. Predictive Power

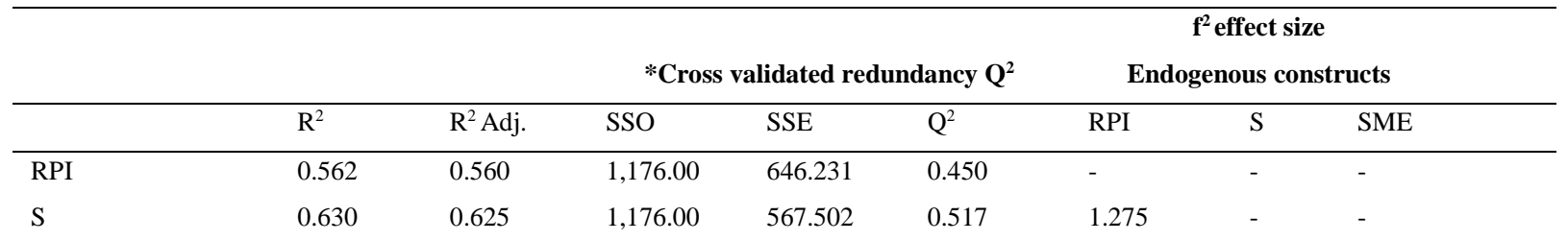




$\begin{array}{lllllllll}\text { SME } & 0.002 & -0.003 & 1,176.00 & 1,176.69 & -0.001 & 0.000 & 0.004 & - \\ \text { IQ } & - & - & 1,176.00 & 1,176.00 & - & - & 0.366 & 0.001 \\ \text { AD } & - & - & 1,568.00 & 1,568.00 & - & - & 0.185 & 0.001\end{array}$

Note: Blindfolding procedure results with an omission distance of 9. Value of R-squared 0,67 (substance/good category); R-squared 0,33 (moderate); and R-squared 0,19 (weak). Effect size 0.02 (weak); effect size 0.15 (moderate); and effect size 0.35 (substance). Q2 predictive relevance > 0 (good predictive).

\section{CONCLUSION}

The purpose of this study is to investigate the antecedents of repurchase intention towards the Traveloka app. The previous research indicates that information quality, application design, and social media engagement determine repurchase intention. Thus, the research hypothesis was built on understanding the association among variables. This hypothesis was developed based on various relevant previous studies and related theories. The analysis demonstrates that the quality of information on the Traveloka application has a significant impact on creating consumer satisfaction in using the Traveloka application. Likewise, with the design of the Traveloka application, it has been proven to have a positive and significant association for the formation of consumer satisfaction when using the Traveloka application.

Interestingly, social media has not been proven to mediate the effect of information quality, application design, and consumer satisfaction on repurchase intention in the Traveloka application. From a practical perspective, it means that information, reviews, or various posts promoted by social media sites about the Traveloka application do not have an impact on consumers repurchase intention decisions in Traveloka. Thus, Traveloka is better focused on how companies can provide and maintain excellent and accurate quality information and the design of Traveloka applications to sustain consumers' satisfaction in using the Traveloka application. The effort can be achieved through initiatives that are tailored to fit and reach the core of the target audience of Traveloka.

\section{REFERENCE}

Ashfaq, M., Yun, J., Waheed, A., Khan, M. S., \& Farrukh, M. (2019). Customers' Expectation, Satisfaction, and Repurchase Intention of Used Products Online: Empirical Evidence from China. SAGE Open, 1-14. doi: $10.1177 / 2158244019846212$

Azemi, N. A., Zaidi, H., \& Hussin, N. (2017). Information Quality in Organization for Better Decision-Making. International Journal of Academic Research in Business and Social Sciences, 7(12), 429-437. doi:10.6007/IJARBSS/v7-i12/3624

Barnes, S. J., \& Vidgen, R. (2002). An Integrative Approach to the Assessment of E-Commerce Quality. Journal of Electronic Commerce Research, 3(3), 114-127. Retrieved from http://www.jecr.org/sites/default/files/03_3_p02_0.pdf

Bernoff, J., \& Li, C. (2011). Effects of Brand Attitude and Familiarity. The Journal of Marketing, 59(1), 63-77.

Blut, M. (2016). E-Service Quality: Development of a Hierarchical Model. Journal of Retailing, 92(4), 500-517. doi:10.1016/j.jretai.2016.09.002

Bulut, Z. A. (2015, October). Determinants of Repurchase Intention in Online Shopping: A Turkish Consumer's Perspective. International Journal of Business and Social Science, 6(10), 55-63. Retrieved from https://ijbssnet.com/journals/Vol_6_No_10_October_2015/5.pdf

Carl, M. S. (2017, October 10). Non-Cash Payment Transactions Processing in Indonesia. Retrieved December 12, 2019, from Media Advokat Indonesia in Cooperation with ILBI Consulting \& Training: http://www.ssek.com/download/document/Non-

Cash_Payment_Transaction_Processing_in_Indonesia_184.pdf

Chen, J., \& Dibb, S. (2010). Consumer Trust in the Online Retail Context: Exploring the Antecedents and Consequences. Psychology \& Marketing, 27(4), 323-346. doi:10.1002/mar.20334

Chen, Y. R. (2017). Perceived Values of Branded Mobile Media, Consumer Engagement, Business-Consumer Relationship Quality and Purchase Intention: A study of WeChat in China. Public Relations Review, 43, 945-954. doi:10.1016/j.pubrev.2017.07.005 
Chu, R. (2002). Stated-Importance versus Derived-Importance Customer Satisfaction Measurement. Journal of Services Marketing, 16(4), 285-301. doi:10.1108/08876040210433202

DeLone, W. H., \& McLean, E. R. (2004). Measuring e-Commerce Success: Applying the DeLone \& McLean Information Systems Success Model. International Journal of Electronic Commerce, 9(1), 31-47. doi:10.1080/10864415.2004.11044317

Dharmavaram, V., \& Nittala, R. (2018). Service Quality and Customer Satisfaction in Online Banking. International Journal of Online Marketing, 8(2), 45-56. doi:10.4018/IJOM.2018040103

Eisingerich, A. B., Chun, H. H., Liu, Y., Jia, M. H., \& Bell, S. J. (2015, January). Why Recommend A Brand Face-to-Face but Not on Facebook? How Word-of-Mouth on Online Social Sites Differs from Traditional Word-of-Mouth. Journal of Consumer Psychology, 25(1), 120-128. doi:10.1016/j.jcps.2014.05.004

Giese, J. L., \& Cote, J. A. (2000). Defining Consumer Satisfaction. Academy of Marketing Science Review, 1, 122. Retrieved from http://www.amsreview.org/articles/giese01-2000.pdf

Guo, X., Ling, K. C., \& Liu, M. (2012, October). Evaluating Factors Influencing Consumer Satisfaction towards Online Shopping in China. Asian Social Science, 8(13), 40-50. doi:10.5539/ass.v8n13p40

Holloway, B. B., \& Beatty, S. E. (2008). Satisfiers and Dissatisfiers in the Online Environment: A Critical Incident Assessment. Journal of Service Research, 10(4), 347-364.

Ibzan, E., Balarabe, F., \& Jakada, B. (2016). Customer Satisfaction and Repurchase Intention. Developing $\begin{array}{lllll}\text { Country Study, 6(2), } & \text { 96-100. } & \text { Retrieved }\end{array}$ https://www.iiste.org/Journals/index.php/DCS/article/view/28624

Januszewska, M., Jaremen, D. E., \& Nawrocka, E. (2015). The Effects of the Use of ICT by Tourism Enterprises. Szczecin University Scientific Journal No. 883, 16(83), 65-73. doi:10.18276/smt.2015.16-07

Kamath, A. (2019, November 14). Industry Study: eCommerce in Indonesia and How Tokopedia Boosts First Time Conversions by 20\%. Retrieved February 12, 2020, from Moengage: https://www.moengage.com/blog/industry-study-ecommerce-in-indonesia-and-how-tokopedia-boostsfirst-time-conversions/

Keller, K. L. (2009, June). Building Strong Brands in A Modern Marketing Communications Environment. Journal of Marketing Communications, 15(2-3), 139-155. doi:10.1080/13527260902757530

Kim, E., Lin, J. S., \& Sung, Y. (2013). To App or Not to App: Engaging Consumers via Branded Mobile Apps. Journal of Interactive Advertising, 13(1), 53-65. doi:10.1080/15252019.2013.782780

Kim, Y. H., Kim, D. J., \& Wachter, K. (2013). A Study of Mobile User Engagement (MoEN): Engagement Motivations, Perceived Value, Satisfaction, and Continued Engagement Intention. Decision Support Systems, 56, 361-370. doi:10.1016/j.dss.2013.07.002

Kwon, J. M., Bae, J. I., \& Blum, S. C. (2013, March). Mobile Applications in the Hospitality Industry. Journal of Hospitality and Tourism Technology, 4(1), 81-92. doi:10.1108/17579881311302365

Lowry, P. B., \& Gaskin, J. (2014). Partial Least Squares (PLS) Structural Equation Modeling (SEM) for Building and Testing Behavioral Causal Theory: When to Choose It and How to Use It. Transactions on Professional Communication, 57(2), 123-146. doi:10.1109/TPC.2014.2312452

Lwanga, S. K., Lemeshow, S., \& Organization, W. H. (1991). Sample Size Determination in Health Studies : A Practical Manual / S. K. Lwanga and S. Lemeshow. Geneva: World Health Organization.

Meuter, M. L., Ostrom, A., Bitner, M. J., \& Roundtree, R. (2003, November 1). The Influence of Technology Anxiety on Consumer Use and Experiences with Self-Service Technologies. Journal of Business Research, 56(11), 899-906. doi:10.1016/S0148-2963(01)00276-4

Middleton, C., Scheepers, R., \& Tuunainen, V. K. (2014). When Mobile is the Norm: Researching Mobile Information Systems and Mobility as Post-Adoption Phenomena. European Journal of Information Systems, 23(5), 503-512. doi:10.1057/ejis.2014.21

Morgan, J. (2019). E-commerce Payments Trends: Indonesia. (J.P. MORGAN GLOBAL PAYMENT TRENDS) Retrieved January 6, 2020, from Indonesia e-commerce insights: https://www.jpmorgan.com/merchant-services/insights/reports/indonesia

OECD. (2018). OECD Tourism Trends and Policies 2018. Paris: OECD Publishing. Retrieved from https://www.oecd.org/cfe/tourism/2018-Tourism-Trends-Policies-Highlights-ENG.pdf

Pappas, I., Pateli, A., Giannakos, M., \& Chrissikopoulos, V. (2014). Moderating Effects of Online Shopping Experience on Customer Satisfaction and Repurchase Intentions. International Journal of Retail \& Distribution Management, 42(3), 187-204. doi:10.1108/IJRDM-03-2012-0034 
Pazir, D., \& Amin, I. (2015). A Study Of Customer Satisfaction Towards Hotel Industry In Kashmir Valley. International Journal of Management Research \& Review, 5(12), 1117-1123. Retrieved from https://www.researchgate.net/publication/330541280_A_STUDY_OF_CUSTOMER_SATISFACTION_ TOWARDS_HOTEL_INDUSTRY_IN_KASHMIR_VALLEY

Phuong, N. N., \& Trang, T. T. (2018). Repurchase Intention: The Effect of Service Quality, System Quality, Information Quality, and Customer Satisfaction as Mediating Role: A PLS Approach of M-Commerce Ride Hailing Service in Vietnam. AIMI Journals - Marketing and Branding Research, 5, 78-91. doi: $10.33844 / \mathrm{mbr} .2018 .60463$

Razak, N. S., Ahmad, A. H., \& Marimuthu, M. (2016). Effect of Website Quality on Repurchase Intention in Travel Agency's Website in Malaysia. Asia Pacific Journal of Advanced Business and Social Studies, 2(22), 22-30. Retrieved from https://apiar.org.au/wpcontent/uploads/2016/08/3_APJABSS_ICABSS_BRR715_BIZ-22-30.pdf

Ringle, C., Wende, S., \& Becker, J. (2015). SmartPLS 3. SmartPLS GmbH. Retrieved from http://www.smartpls.com

Ryan, D., \& Jones, C. (2012). Understanding Digital Marketing : Mareting Strategies for Engaging the Digital Generation (2nd ed.). London: Kogan Page Publishers.

Sekaran, U., \& Bougie, R. (2016). Research Methods for Business: A Skill-Building Approach (7th ed.). Haddington: John Wiley \& Sons.

Sharma, G., \& Lijuan, W. (2015, June). The Effects of Online Service Quality of E-Commerce Websites. The Electronic Library, 33(3), 468-485. doi:10.1108/EL-10-2013-0193

Statista. (2019, November 21). Indonesia: Number of Internet Users 2017-2023. (Statista Research Department) Retrieved from Statista: https://www.statista.com/statistics/254456/number-of-internet-users-inindonesia/

Statista. (2019, February 22). Internet Usage in Indonesia - Statistics \& Facts. (Statista Research Department) Retrieved from Statista: https://www.statista.com/topics/2431/internet-usage-in-indonesia/

Statista. (2020, January 21). Number of Online Transactions in Indonesia 2011-2019. (Statista Research Department) Retrieved from Statista: https://www.statista.com/statistics/958140/indonesia-onlinetransaction-volume/

Tandon, U., Kiran, R., \& Sah, A. (2017). Analyzing Customer Satisfaction: Users Perspective towards Online Shopping. Nankai Business Review International, 8(3), 266-288. Retrieved from https://econpapers.repec.org/article/emenbripp/nbri-04-2016-0012.htm

Wang, H. Y., \& Wang, S. H. (2010, December 1). Predicting Mobile Hotel Reservation Adoption: Insight from A Perceived Value Standpoint. International Journal of Hospitality Management, 29(4), 598-608. doi:10.1016/j.ijhm.2009.11.001

Wang, Y. S., \& Liao, Y. W. (2007). The Conceptualization and Measurement of M-Commerce User Satisfaction. Computers in Human Behavior, 23(1), 381-398. doi:10.1016/j.chb.2004.10.017

Yang, H. C. (2013). Bon Appétit for Apps: Young American Consumer's Acceptance of Mobile Applications. Journal of Computer Information Systems, 53(3), 85-96. doi:10.1080/08874417.2013.11645635

Yoong, L. C., \& Lian, S. B. (2019). Customer Engagement in Social Media and Purchase Intentions in the Hotel Industry. International Journal of Academic Research in Business and Social Sciences, 9(1), 54-68. doi:10.6007/IJARBSS/v9-i1/5363

Zeithaml, V. A. (1988, July). Consumer Perceptions of Price, Quality and Value: A Mean-End Model and Synthesis of Evidence. Journal of Marketing, 52(3), 2-22. doi:10.2307/1251446 